\title{
Diverging Paths? Institutional Autonomy and Academic Freedom in the European Higher Education Area
}

\author{
Liviu Matei and Julia Iwinska
}

It is possible to analyse in a systematic manner the evolution of university autonomy and academic freedom in Europe after 1999-2000, a distinct and remarkable period in the history of European higher education. A consistent, albeit surprising, pattern can be identified: it consists of a combination of diverging paths of development. We define the path of development as a distinguishable, cohesive, interconnected and relatively stable sequence of events or changes taking place over a longer period in a given area, which are characterised by a distinctive combination of speed, direction and substance (content). To illustrate briefly, we propose two examples, which we will analyse in this chapter.

We argue that there is a difference of direction, speed and content, or different paths of development, in the evolution of institutional autonomy compared to academic freedom: this period shows much faster and mainly progressive changes in autonomy, as opposed to slower and rather regressive changes in academic freedom in Europe, both at the conceptual level and in practice. If we look at autonomy alone, we notice a particular path of development: an accelerating tendency to define, measure and practice it in relation to efficiency, rather than intellectual, moral and legal references, including human rights. We call this the instrumental path of development of autonomy in the EHEA.

In this chapter, we attempt to identify the most important paths of development in academic freedom and university autonomy in the EHEA, analyse their interaction and explore their significance for the broader discussion about the present and future of higher education in Europe.

L. Matei $(\bowtie) \cdot$ J. Iwinska

Central European University, Budapest, Hungary

e-mail: mateil@ceu.edu

J. Iwinska

e-mail: iwinskaj@ceu.edu

(C) The Author(s) 2018

A. Curaj et al. (eds.), European Higher Education Area: The Impact of Past and Future Policies, https://doi.org/10.1007/978-3-319-77407-7_22 
The period since the beginning of the Bologna Process in 1999 has been one of the most extraordinary in the history of higher education in Europe and indeed in the world (Matei et al. 2018; Scott 2012; Vögtle and Martens 2014). The magnitude of changes it triggered has been qualified as similar to the "tectonic shifts" in geology (Matei 2012; Matei and Curaj 2014). All areas of higher education have been touched upon in significant ways. Not surprisingly, they include university governance - how universities are organised, operated and controlled - and academic freedom and university autonomy as aspects, or areas of governance.

The Bologna Process aimed at the creation of a new space of policy dialogue and practice in higher education, resulting in the establishment of the European Higher Education Area as of 2010. In this space, new attitudes vis-à-vis governance emerged; new concepts, principles and tools have been experimented with, some of which have attracted attention outside Europe as well (Vögtle and Martens 2014; Gornitzka et al. 2017). University governance in Europe has undergone significant changes since 1990-2000 at the institutional, national and European level. Developments at the European level might appear to be the most salient and important. That is because the very emergence of the EHEA as a continental, sui generis and larger-than-life space for higher education generated new, continent-wide models, practices and also challenges in the area of governance, some unprecedented, which had to be dealt with. Because they are new and large, developments and challenges at the European level might be easier to recognise and more interesting to study. One could perhaps even characterise the EHEA in its entirety as a new entity that requires new forms of governance. We could speak of the EHEA as a new space for governance in higher education. Vukasovic et al. consider that the special nature of governance in the EHEA is expressed in a distinctive combination of three characteristics: it is multi-level, multi-stakeholder and multi-issue (Vukasovic et al., this volume).

Not all changes in European higher education during this period are the result of planned, continental "tectonic shifts" like the Bologna Process and the European Higher Education Area, or the related project of a European Research Area. ${ }^{1}$ More or less independent national reforms, policy and regulatory initiatives have also played an important role. Global trends are not to be ignored either. Moreover, for our specific subject in this chapter, aside from a generic plea for institutional

\footnotetext{
${ }^{1}$ The Bologna Process, launched with the Bologna Declaration of 1999, is a voluntary intergovernmental process in higher education based on jointly agreed principles, objectives and standards. Currently, there are 48 European states implementing the Bologna Process, which constitute the European Higher Education Area (EHEA). The EHEA, as the common European space for higher education, is considered a result of the Bologna Process. A European Research Area (ERA), which emerged at about the same time with the EHEA, developed as a major initiative under the Lisbon Agenda, the EU's overarching strategy between 2000 and 2010. ERA is defined as a "unified research area open to the world based on the Internal Market, in which researchers, scientific knowledge and technology circulate freely and through which the Union and its Member States strengthen their scientific and technological bases, their competitiveness and their capacity to collectively address grand challenges" (Treaty of Lisbon amending the Treaty on European Union and the Treaty establishing the European Community, signed at Lisbon, 13 December 2007).
} 
autonomy, academic freedom and stakeholder participation, there has been only rare and little explicit focus on governance as part of the Bologna Process. This is reflected in the official programmatic documents of the Process, including the communiqués adopted at the regular gatherings of the ministers in charge of higher education of the participating countries (the highest governance level of the EHEA). The Bucharest Communiqué, for example, calls only generically for more policy dialogue on university governance and reiterates the commitment of the ministers "to autonomous and accountable higher education institutions that embrace academic freedom" (Bucharest Communiqué 2012). A paper on university autonomy and academic freedom as fundamental values of the EHEA (Bergan et al. 2016) was discussed in 2016 at a dedicated thematic session of the Bologna Follow Up Group, a rare effort to explicitly put these topics on the agenda of the Process. It appears that there was no policy or practical follow up from this discussion, in spite of the name of this body. ${ }^{2}$ Yet, it can be argued that there are important elements of European specificity in the evolution of university autonomy and academic freedom emerging primarily because of and in relation to the Bologna Process. The involvement of the European Union, whether directly within the Process (the European Commission is a member along with 48 countries) or through related initiatives, is also noticeable.

What are these uniquely European elements? How have the two related concepts and principles, university autonomy and academic freedom, evolved since 1999 ?

In one of the most authoritative publications of our times on university autonomy, it is stated that "there is no uniform trend towards autonomy in Europe" (Tarrach 2017, p. 5). We concur with this assessment, although it may sound discouraging. It is based on thorough research and abundant evidence. The same could be stated, in fact, about academic freedom. Moreover, we could add to that: not only that there is no uniform trend, but at a closer look we can recognise a number of significantly diverging paths in the evolution of university autonomy and academic freedom in Europe after 1999-2000. What is more important, however, is that we can identify these paths with some degree of precision and observe that, although diverging, they sketch a clear and consistent pattern.

Before scrutinizing individual paths, their significance and that of the overall pattern, we discuss briefly the two concepts under consideration, academic freedom and university (or institutional) autonomy. ${ }^{3}$

\footnotetext{
2“The Bologna Follow-Up Group (BFUG) is the executive structure supporting the Bologna Process in-between the Ministerial Conferences. It is in place since autumn 1999". Cf. https:// www.ehea.info/pid34247/how-does-the-bologna-process-work.html, accessed on 10 January 2018.

${ }^{3}$ Throughout this chapter, we refer to autonomy as an area of governance of all higher education institutions, not just universities, and use the two terms, university autonomy and institutional autonomy, interchangeably.
} 


\section{University Autonomy and Academic Freedom}

Surprisingly, university autonomy and academic freedom are rarely discussed concurrently in the scholarship about the EHEA. Why talk about them together? Because they are intimately related, although different concepts (see Ren and Li 2013; Matei 2017 for comparative discussions of the two concepts). Academic freedom and university autonomy refer in essence to a single constitutive, defining characteristic of the university as an institution: certain freedom, or freedoms, for both the individuals within it and for the institution are needed in order to fulfil its core mission. Simply stated, the mission of the university is the pursuit of, and the contribution to, the production of knowledge (the quest for truth through research and scholarship), as well as the transmission and dissemination of knowledge (primarily through teaching and learning). We may also add a broader educational function, which goes beyond the simple transmission of knowledge. Academic freedom and university autonomy are related to other freedoms, such as freedom of speech, freedom of opinion, freedom of assembly, or freedom of movement (Beiter et al. 2016). Still, academic freedom and university autonomy are different from these other freedoms. They are restricted to the sphere of higher education (research, and teaching and learning, primarily) and are subject to specific limitations and obligations. Importantly, they include the obligation to produce and transmit knowledge as a public good and to observe defined academic (including disciplinary) standards, regulations, and practices.

Academic freedom and university autonomy are concepts that are difficult to define and principles that are difficult to put into practice, let alone in a unified way. This difficulty has multiple sources. One of them has to do with cultural, political, and historical variability: we can think of the definition of academic freedom in medieval versus contemporary Europe, for example, or in China and the U.S. in our days. Another reason has to do with an implication that academic freedom and autonomy make universities exceptional institutions. Universities are "exceptional" because they provide or contribute to the provision of an exceptional public good or service to society: knowledge (Marginson 2016). In turn, in order to be able to provide this good, to fulfil their mission, universities need a certain degree of "exceptional" freedoms (academic freedom and institutional autonomy). They are exceptional freedoms because they are of a type that other institutions or professionals in the society do not benefit from. Scholars of academic freedom and autonomy insist on the fact that the "special" freedoms of the university are needed, justified, and should only be practised in order to fulfil a social function, not for the benefit of the universities themselves or for the private benefit of individuals inside the university. In this way, they are as much rights as they are duties and responsibilities (Ren and Li 2013; Beiter et al. 2016).

The nature of the two concepts is complex, which adds to the difficulty of defining and putting them into practice. Sometimes, it is argued that "freedom" in the concept of academic freedom should be understood in a moral rather than only functional perspective, given that universities are more than just tools for the 
delivery of social goods - their work has to do with rights (Beiter et al. 2016). They include human rights, for example the right to education of the citizenry. Some other times, academic freedom and university autonomy are represented rather as instrumental principles having to do with efficiency: it is then argued that universities cannot fulfil their functions, however defined, in an efficient manner under conditions of overwhelming external control (Matei and Iwinska 2014; Pruvot and Estermann 2017). The link between university governance (academic freedom, in particular) and rights is not easy to acknowledge, regulate and practice. One of the few international documents dedicated to academic freedom and university autonomy sheds some light on this matter. It expresses concern "regarding the vulnerability of the academic community to untoward political pressures which could undermine academic freedom" and states that "the right to education, teaching and research can only be fully enjoyed in an atmosphere of academic freedom and autonomy for institutions of higher education and that the open communication of findings, hypotheses and opinions lies at the very heart of higher education and provides the strongest guarantee of the accuracy and objectivity of scholarship and research" (UNESCO 1997, Preamble),

Internal university actors, as well as key external stakeholders often confuse the two concepts. Sometimes, only one of them is used. Often, they are taken to be identical. We argue for the importance of distinguishing between the two concepts in the EHEA. Moreover, not only are they distinguishable but both are important.

The distinction between academic freedom and university autonomy is contested and differently understood in various contexts (Matei 2017; Ren and Li 2013). Most often, academic freedom is understood as the freedom of individual academics and students to teach, study and pursue education and research without undue interference or restriction from law, institutional regulations or public pressure. University autonomy, on the other hand, is of the institution, not the individual. It is about the right of the university to determine its organisation and administrative structures, to decide on priorities, manage its budget, hire personnel and admit students, decide on the content and form of its teaching and research (Matei 2017). It can be stated that institutional autonomy, as a set of freedoms of the institution, is a precondition for academic freedom, as a set of freedoms for individuals in the institution (Kenesei 2017).

Matters of academic freedom are more salient in certain countries; in others, institutional autonomy is more critical. In the U.S., institutional autonomy is often taken for granted, at least in the case of private universities, and what is more debated is academic freedom. In other countries, such as in many parts of contemporary post-Soviet region, Turkey, or Hungary, institutional autonomy is severely restricted, which makes it a more urgent matter to discuss and attend to (Matei 2017).

Academic freedom and institutional autonomy are not binary, yes-or-no variables. They are not one-dimensional either. The European notion of university autonomy developed by the European University Autonomy, discussed below in this chapter, assumes four main dimensions (organisational, financial, staffing, and academic autonomy), with over 20 (Pruvot and Estermann 2017) or 30 
sub-dimensions (EUA online autonomy tool ${ }^{4}$ ). Other models focus on anything between only three main dimensions to up to eight (see Matei and Iwinska 2014 for a comprehensive analysis of various models of autonomy). In a detailed proposal for a definition of academic freedom for the European Union, Karran distinguishes among four main components or dimensions: teaching, research, self-governance and tenure (Karran 2009).

Academic freedom and university autonomy are a matter of degree. There is more or less freedom, but no absolute freedom for the university anywhere (Matei 2017). Autonomy is not a discrete variable that can be reflected in a single index or measure, but rather as a combination or configuration of dimensions and degrees (Matei and Iwinska 2014; Matei 2017). It is possible, in this way, to distinguish specific configurations for specific countries, even country profiles, as illustrated by a recent monitoring study in Europe (European University Association 2017). We suggest that profiles combining actual dimensions of autonomy and academic freedom can be sketched for individual universities as well.

The fact that academic freedom and university autonomy consist of several dimensions helps explain in part the existence of diverging paths of development. It is possible to witness rapid and major positive changes on a certain dimension, for example, managerial autonomy, but negative developments on other dimensions, such as strategic autonomy, as discussed in Sect. 2.b.

A distressful but highly illustrative example of how the two concepts are different but related is the case of Central European University (CEU), which has faced attacks from the Government of Hungary since spring 2017 (Matei and Orosz 2017). These attacks can be interpreted as directed against university autonomy. The Hungarian Government did not act or attempt to act directly against CEU's individual faculty members or students, against their individual freedom to pursue the study of a particular subject or publish a paper on a given topic. This was not about censorship of academic work. Rather, it was an attack against CEU as an institution, its right to decide on how to organise its work, administrative operations and governance structures. This is a painful case of severe restrictions of university autonomy in a European Union/EHEA country, to the point of putting at risk the continuity of operations of this university altogether. Restrictions on autonomy, in turn, do have an impact on academic freedom as the right of individual academics and students to pursue education and research.

The understanding of academic freedom and autonomy differs along temporal and cultural axes, and it is influenced by what we could call situated epistemologies. Ren and Li (2013) review a corpus of literature focusing on the differences between the European, American and Chinese definitions/understandings and practice of academic freedom and university autonomy, as influenced by particular epistemologies. Specifically, they refer to the rationalist tradition in Europe, pragmatism in the U.S. and Confucianism in China. It would be possible to use a similar analytic approach in studying the evolutions in the understanding and practice of

\footnotetext{
${ }^{4}$ http://www.university-autonomy.eu accessed on 3 January 2018.
} 
university autonomy and academic freedom in the EHEA. We could inquire whether the emergence of the EHEA has taken place in a specific epistemological milieu, which, in turn, might have influenced how academic freedom and university autonomy are understood and practised. We do not undertake an extended analysis along these lines in the present chapter but will refer briefly to possible elements of the social and political epistemology in the EHEA in the section on the European notion of university autonomy.

\section{Diverging Paths in Academic Freedom and University Autonomy in the European Higher Education Area}

a. The disjunction between university autonomy and academic freedom in the EHEA.

Diverging paths of development of university autonomy and academic freedom can be traced looking into the existence, behaviours and evolutions of any organisation engaged in the defence, promotion, codification and regulation of the two principles, associated policy discourses and policy initiatives, and of course actual practices.

The first observation is the absence of European-wide or national organisations explicitly and effectively dedicated to the promotion and defence of academic freedom. Various organisations in Europe, for example, university associations and courts, do occasionally play a role in the defence of academic freedom. These organisations, however, are not dedicated to or focused on academic freedom, their role is uncertain (difficult to predict) and they are most often inefficient and rarely significant vis-à-vis academic freedom. This situation in the area of academic freedom in the EHEA is different from the U.S., for example, and also different from the situation of autonomy in Europe.

In the United States, the American Association of University Professors (AAUP), established in 1915, remains a powerful organisation until today, looming large over the entire higher education system in the U.S. regarding the definition, promotion, defence and practice of academic freedom. The principles on academic freedom and academic tenure, first put forward in the 1915 AAUP Declaration of Principles, modified later and endorsed also by the Association of American Colleges (currently the Association of American Universities and CollegesAAUC), remain the most important reference for academic freedom in the United States. It is a powerful and influential form of codification of academic freedom, which bears, beyond conceptual and policy references, undeniable legal value, as evidenced by many court cases.

There had been no similar codification of academic freedom in Europe. None has emerged after 1999-2000 as part of the Bologna-stimulated developments either. There had been no organisation in Europe to represent the counterpart of AAUP earlier and none has been created since 1999-2000. 
In 1988, the rectors of several European universities adopted the Magna Charta Universitatum, and a Magna Charta Observatory was created, ${ }^{5}$ which could have played a role in Europe similar to that of AAUP in the U.S. Started as a European initiative dedicated both to academic freedom and institutional autonomy, Magna Charta has been signed by now by over 800 universities from over 80 countries from all parts of the world. Although Magna Charta Universitatum is a European document, explicitly identified as such in the text, this initiative has acquired a much broader international scope. Even more important for our discussion here are four additional aspects related to Magna Charta Universitatum and Observatory. First, the Magna Charta Observatory, as an institution, is a devoted guardian of the Magna Charta and its principles. However, it lacks the authority to effectively promote, let alone enforce, them. Second, the Magna Charta as a document serves as an important, worldwide by now, but overly general reference to a set of values. As an organisation, the Magna Charta Observatory is not operational in the way the AAUP or AAUC are. It has very limited resources and staff. It does not have a clear mandate to engage operationally in the defence of academic freedom, for example by taking up individual cases. Third, the Magna Charta Observatory has undertaken some good but limited work in promoting these values mainly through conferences and publications. It lacks not only human resources but also the tools to do more. Fourth, it is dedicated primarily to institutional freedoms, focusing almost all its work on university autonomy rather than academic freedom.

Unlike in the case of academic freedom, a very powerful actor has emerged in Europe and it asserts great influence in the definition, operationalisation, measurement and promotion of university autonomy: the European University Association (EUA). Since its establishment in 2001 as the collective voice of European universities, EUA has played a key role, in partnership with other organisations, in the design and implementation of key elements of the European Higher Education Area, such as European standards and guidelines for quality assurance, ${ }^{6}$ or the European qualifications framework for higher education, ${ }^{7}$ to mention only two. Today, we would argue, EUA is one of the most important actors in European higher education. Like all other major actors in the EHEA, however, EUA has paid little attention to academic freedom. In turn, it has made, possibly, the most important contribution to the definition and operationalisation of institutional autonomy in Europe, to the advent of a European notion of university autonomy as we experience it today, and which is probably here to stay for years to come. Three EUA hallmark reports on university autonomy in Europe published in $2009,2011,2017$, a related report on autonomy country profiles published in 2017, and an interactive online tool ${ }^{8}$ are formally only about monitoring, comparing, and

\footnotetext{
${ }^{5}$ http://www.magna-charta.org/, accessed on 10 January 2018.

${ }^{6} \mathrm{http}: / /$ www.enqa.eu/wp-content/uploads/2015/11/ESG_2015.pdf, accessed on 8 January 2018.

${ }^{7}$ http://www.ehea.info/cid102842/qualifications-frameworks-in-the-ehea-2009.html, accessed on 8 January 2018.

${ }^{8}$ Available at http://www.university-autonomy.eu/ accessed on 5 January 2018.
} 
measuring different elements of institutional autonomy in around 30 European higher education systems (Estermann and Nokkala 2009; Estermann et al. 2011; Pruvot and Estermann 2017; European University Association 2017). In reality, this series of reports has put forward and codified a new, European conception of university autonomy. As is often the case in public policy, an exercise in measuring has become an exercise in definition and codification. The EUA Autonomy Reports and the conception of university autonomy they foster have become very influential in Europe with individual higher education institutions, the media, national authorities and supra-national European actors. Moreover, this conception has become influential in other parts of the world as well.

We argue that the EHEA has "codified" institutional autonomy. Or, to be more exact, EUA has codified university autonomy in the EHEA, whether it intended to do so or not.

We may ask why it is relevant to expect developments in the EHEA in both areas, university autonomy and academic freedom, and perhaps synchronised, as opposed to diverging, paths. This is an important question for several reasons. First, as discussed above, academic freedom and university autonomy are intimately related concepts. They contribute to defining the university as an institution and represent key conditions allowing its operation as a particular, even exceptional, type of institution. Universities cannot pursue and fulfil their mission in the absence of a certain degree of freedom, or freedoms, both institutional and individual, which need to be codified and supported by regulations. Second, as a new space for dialogue and practice in higher education, the EHEA brought about new remarkable ambitions (e.g. supporting the emergence of a European demos and ethos; Matei 2015), new epistemologies and new regulatory realities for higher education, including the emergence of the EHEA itself as a new entity for higher education governance. All these advances could have been expected to result in, and even require, new developments in both academic freedom and university autonomy. For example, the new role of the state in view of the emergence of a supra-national, European-space for higher education governance could have been expected to result in new codification, regulations, tools and institutions at the European level in defence of the specific responsibilities and freedoms of the university, including academic freedom and institutional autonomy. So far, this has succeeded only for autonomy - which is not to say that no attempts have been made in the area of academic freedom. We can highlight the adoption of the Magna Charta Universitatum and the creation of the Magna Charta Observatory, discussed above, or the proposal to adopt a European Union definition of academic freedom (Karran 2009). The later initiative might be worth revisiting. The Council of Europe, an international organisation (different from the European Union) created in 1949 to uphold human rights, democracy, rule of law in Europe and promote European culture (47 member states at present) has endeavoured systematically to promote and defend both academic freedom and university autonomy. For example, the Parliamentary Assembly of the Council of Europe adopted a Recommendation in 2006 referring to the Magna Charta Universitatum and addressing a specific situation of restriction of academic freedom emerging at that time in Belarus. The 
Recommendation calls on the member states to assume responsibility for the protection of academic freedom and institutional autonomy (Council of Europe 2006). A more recent document from the Council of Europe points even more specifically and forcefully to the responsibility of public authorities for academic freedom and institutional autonomy as being directly linked with democracy, human rights and the rule of law (Council of Europe 2012). The European Union has also tried to promote a European attitude and action with regard to academic freedom. In the case of the attacks against CEU discussed briefly above, the European Commission initiated legal action against the Hungarian Government and deferred the matter to the European Court of Justice for a legal decision (European Commission 2017). One of the main arguments in the motivation of the Commission for turning to the Court was very specifically its assessment that the Hungarian Government, through its actions following the adoption of the so-called "Lex CEU" (the revised Hungarian Higher Education Law of 2017) acted against the European legislation, including European legislation on academic freedom. Interestingly, the Hungarian Government claimed in its responses to the Commission that legislating on higher education is a matter of exclusive national competence and that there is no European legislation on academic freedom anyway ${ }^{9}$ (Hungarian Government 2017).

We see in these examples that attempts to develop new definitions, regulations and practice of academic freedom in the EHEA have been made. They represent perhaps a recognition of the need to act in this area. Only that these attempts have been few, not significant and fundamentally unsuccessful.

When discussing the lack of European or EHEA-wide codification in the area of academic freedom, we do not ignore the fact that some elements of codification for both academic freedom and university autonomy do exist (Beiter et al. 2016). They include national constitutions, many of which contain provisions regarding academic freedom (18 European countries) and institutional autonomy (15 countries, Beiter et al., ibid). National higher education legislation also occasionally includes provisions about one, the other, or even both areas (Beiter et al., ibid). In addition, certain international treaties and other documents include provisions that may apply, often indirectly and without binding legal force, to academic freedom and institutional autonomy at the national level. For Europe, the most important international references are the European Convention on Human Rights (adopted in 1950, the International Covenant on Civil and Political Rights and the International Covenant on Economic, Social and Cultural Rights (both of 1966) and the UNESCO Recommendation concerning the Status of Higher-Education Teaching Personnel (1997). In a very few cases, national and European courts have passed verdicts on matters touching on autonomy and academic freedom, thus contributing in this way some new form of codification.

\footnotetext{
${ }^{9}$ The Hungarian Government had already modified the national legislation (starting with the revision of the Constitution of Hungary in 2010) before Lex CEU to restrict academic freedom and autonomy (Chikan 2017; Kenesei 2017; Tausz 2017).
} 
b. Development of institutional autonomy at the expense of academic freedom?

More diverging paths become visible when we assess whether developments in Europe in these two areas since 1999-2000 constitute progress. We argue that the Bologna Process and the emergence of the EHEA created conditions for the advancement of university autonomy, both conceptually and in practice. This was not the case with academic freedom.

The creation of a transnational, European-wide space for higher education has contributed to reducing the grip of the state on universities in most countries of the continent. The Bologna Process and the EHEA, as well as the ERA, brought about new transnational cooperation possibilities; European - as opposed to only national regulations and organisations (such as with regard to accreditation, for example); and the availability of European funding, directly to higher education institutions, as opposed to only national funding. All this has made possible for universities to take some distance and enjoy new freedom from their governments. The EHEA has indeed created a new space for more autonomous operations of European universities.

In the same period, the European Union also put great emphasis on developing university autonomy. As part of its modernisation agenda for higher education, the European Commission insisted that European universities have insufficient autonomy, mainly because they are "prisoners" in the hands of the state and subject to undue control by the state. The Commission also took issue with the prevalently national principles in the organisation of higher education in Europe. It considered that the lack of autonomy and leaving universities at the hand of national states are counterproductive and must be overcome. This is directly stated in one of the first documents outlining the parameters of the modernisation agenda:

Member States value their universities highly and many have tried to "preserve" them at national level through detailed regulations organising them, controlling them, micromanaging them and, in the end, imposing an undesirable degree of uniformity on them.

(European Commission 2006, p. 11)

In line with global trends continuing from the previous periods, many governments in Europe introduced changes to national regulations and practices that brought about more institutional freedom for universities in managing their internal affairs, for example by replacing line budgeting with block grants. This may be interpreted as increased autonomy. In reality, however, the situation is more complex. To understand it, we need to go back to the characterization of autonomy as a multidimensional concept. We will find out in this way that, as documented by existing research, there has been progress on certain dimensions of autonomy, at least in some countries, but not on others and not in all countries (de Boer and Jongbloed 2012; Pruvot and Estermann 2017).

A comparative empiric study of university governance in several European countries (de Boer and Jongbloed 2012) found that many decisional prerogatives have indeed been devolved by the state to universities themselves, which might appear as increased autonomy. In another study, Enders et al. found increased 
regulatory autonomy for universities in the Netherlands in concert with increased institutional performance expectations from the state (Enders et al. 2012). At the same time, however, the state has preserved important control functions, in particular with regard to defining the functions and objectives of autonomy itself. The conclusion is that, while universities in the countries studied have indeed acquired "managerial autonomy" or "regulatory autonomy" (de Boer and Jongbloed 2012; Enders et al. 2012), they continue to lack what other authors would call strategic autonomy (Abrami et al. 2014; Zhao and Hayhoe 2014). Universities have more freedom to manage their internal operations than before, but not much freedom to decide what is the purpose of these operations and perhaps simply what universities are for. This remains largely a central government prerogative. We can speak of a new type of diverging path here: progressive developments in certain dimensions of autonomy but no or even regressive developments (new restrictions) in other aspects.

Additional diverging paths become visible when we look at differential developments in institutional autonomy and academic freedom. The new transnational space created by the Bologna Process has indeed contributed to freeing universities from "captivity in the hands of the state", at least in some dimensions, thus making more freedom for the institutions (autonomy) possible. At the same time, it is not clear whether this process was accompanied by a corresponding progress in terms of freedom for the individuals in universities (academic freedom). It has been argued that rather the contrary has happened: universities as institutions have acquired some more freedom or freedoms, but the freedom or freedoms of academics have been reduced. Beiter et al. (2016) discuss the increased freedom of university with regard to hiring, promoting and retaining academic and administrative staff (staffing autonomy, in the EUA classification). The increased autonomy of universities to hire academic staff on limited and short-term contracts, in particular, made possible by new national regulations is interpreted as a departure from the previous tenure or tenure-like mode of appointment, resulting in limitations to academic freedom, at the same time with the expansion of university autonomy (Beiter et al. 2016).

To give another example, universities in most countries of the former Soviet Union have experienced increased levels of autonomy-academic autonomy in particular (Sagintayev and Kurakbayev 2015), although at a different pace. They were allowed to decide internally on an increasingly larger part of the curriculum, moving away from the previous centralised decision-making reflected in the so-called state-standards of the Soviet times. This meant more freedom for the institution but not necessarily more freedom for individual academics and students.

There are many situations of restriction of academic freedom in the EHEA during this period, by way of regulations and administrative action, and even extreme attacks in individual cases, such as those in Turkey in the wake of the 2016 coup, using as an argument, or pretext, the alleged involvement of students, academic and university administrators (Caglar 2017) in a coup d'état attempt in 2016. Unfortunately, there is no systematic research available on the evolution of academic freedom in the EHEA, not even simple inventories of individual cases of 
restrictions or attacks on academic freedom. ${ }^{10}$ Existing evidence is more or less anecdotic. Nevertheless, if academic freedom and university autonomy are facets of a necessary principle or condition in higher education (freedoms in and for the university), these examples alone point clearly to divergent paths of developments between academic freedom and university autonomy.

c. Disjunction between instrumental aspects and moral or human rights aspects.

We discussed in the previous section diverging paths in the evolution of academic freedom and university autonomy in the EHEA. We propose a possible explanation for this situation, which has to do with another, broader path in university governance.

There has been a strong tendency during this period to focus on what we propose to call instrumental aspects of governance, at the expense of moral aspects, or related to rights. Research shows that policymakers, other external stakeholders and universities themselves tended to focus on instrumental aspects of governance, in search for increased institutional efficiency, or performance (usually externally defined):

Over the last decades many national reforms have been initiated in Europe with the aim of strengthening the executive capacity of public universities. The reform agendas had a number of items in common, including the enhancement of institutional autonomy, the professionalisation of institutional leadership and administration, and the introduction of more competitive, performance-oriented funding models (Gornitzka et al. 2017, p. 274)

Enders et al. point to the emergence of "autonomy policies for strengthening managerial discretion and internal control of universities that are combined with regulatory policies for external control that steer organisational choices". They found that "regulatory autonomy (...) aims at aligning universities more closely with governmental goals and improve respective performance" (Enders et al. 2012, p. 5). This trend could explain other significant developments in university autonomy and academic freedom in the EHEA.

First, it could explain the relative disregard for academic freedom. Academic freedom is more directly linked to moral aspects, rights and other freedoms, and its link to institutional performance is subtler and more difficult to grasp and assert. University autonomy, in turn, is more directly prone to be put to the service of performance, in particular as seen from a public policy perspective.

A broader reorientation of the university has taken place in the age of the knowledge society everywhere, not just in the EHEA, leading to its gradual transformation into something more similar to other organisations (thus not that exceptional). Like other organisations, the university needs to "deliver" externally

\footnotetext{
${ }^{10}$ The Scholars at Risk Network's Academic Freedom Monitor is probably the largest inventory of cases of violation of academic freedom worldwide. As of January 2018, the website lists only five cases of violation of academic freedom in Europe in 2017, including the analysed case of CEU but also a case in Belgium, along with cases in Belarus and Russia. Cf. http://monitoring. academicfreedom.info/map/europe, accessed on 6 January 2018.
} 
defined products, such as employability, jobs, patents or income, and not generic education, knowledge or truth. This trend has been extensively discussed, whether approvingly or not, in the higher education scholarship. It has been sometimes considered to have resulted in drastic changes with regard to autonomy and academic freedom. The question has been even asked whether, as part of this evolution, universities have sacrificed academic freedom and autonomy on the altar of commercialisation - that is, for money (Forsyth 2014). In studies concentrating on the EHEA, it is implied that, by focusing on efficiency in higher education (on "products") and ignoring rights, autonomy arrived to be privileged over academic freedom. Beiter et al. criticise the EUA model of autonomy as revealing flows when analysed from a human rights perspective. They even imply that this model sacrifices academic freedom altogether on the altar of autonomy (Beiter et al. 2016).

Second, out of concern for efficiency, not only is autonomy privileged over academic freedom but autonomy itself is conceptualised in a manner that makes it much more, if not exclusively, an instrumental concept or principle that is supposed to serve the capacity of the university to "deliver" better. The EUA model could be considered a good illustration of this trend.

Third, the instrumental focus and the reduced or lack of consideration for aspects having to do with rights might explain the evolutions with regard to codification, in particular legal codification, of academic freedom and university autonomy. When recognised, rights need to be protected through legal regulations, whether national and international. If autonomy and academic freedom are not perceived to be linked to rights, we should not be surprised that there is not much progress with regard to their legal codification in the EHEA. This may also explain, again at least in part, why no organisation has emerged in Europe dedicated to the promotion and legal protection of autonomy and academic freedom. Moreover, even existing legal regulations applicable to these two areas tended to be forgotten and fell into desuetude, as deplored by Beiter et al. (ibid) or Karran (2009). Here too, some attempts in the opposite direction have been made, like the inclusion of provisions about academic freedom in the failed project of a European Constitution (Karran, ibid). Just that, once again, such attempts have been very few and unsuccessful. Even worse, in some countries, such as Hungary, we have witnessed negative developments: existing constitutional and other legal provisions that were favourable and progressive explicitly referring to academic freedom and autonomy have been replaced with new, restrictive ones for both areas after 2010, as discussed in this chapter. Finally, when important developments did take place with regard to codification, such as in the case of the EUA model of autonomy, the focus was on efficiency and there was no serious attention to rights, generically or from a legal perspective.

We may ask what is wrong with this trend, with the focus on instrumentality and efficiency. We can identify several problematic aspects:

- Moving away from the understanding, codification and practice of academic freedom and university autonomy in terms of, or with reference to, rights makes their defence more difficult. The lack of legal anchoring of the two concepts or 
principles makes their practice more difficult and uncertain. How do all the actors involved know what these principles are about, or has the authority to define and regulate them and issue guidelines?

- Ignoring the moral and rights facets of university autonomy and academic freedom leads to a confusing understanding of the two concepts, which might, in turn, have a negative impact on performance or efficiency.

- Finally, ignoring rights considerations is problematic in itself. Even more so as academic freedom and university autonomy are based on, or related to, important democratic rights and moral principles, such as freedom of speech, freedom of association, freedom of movement, or freedom to education.

For these reasons, we would agree with those, very few, who are calling for a reintegration of the moral and rights perspective in the discussion about academic freedom and university autonomy in the EHEA.

d. Diverging geographies. Scattered geographic picture of university autonomy and academic freedom within the EHEA, in spite of common trends.

As a common space for policy dialogue and action in higher education, the EHEA is not a monolithic area. There are many differences across and within its countries and sub-regions. The same is true for the evolutions of academic freedom and university autonomy, in spite of a certain unifying force of the EHEA and common trends. We can notice diverse and occasionally diverging everyday (informal) understandings of the two notions, as well as differences in their formal codification and practice.

The overall evolution of the understanding of the two concepts appears largely similar for the entire EHEA. As discussed in this chapter, a European notion of autonomy has emerged, at least nominally. As a common reference if not as a legally binding concept. At the same time, just about everywhere in the EHEA attention to academic freedom as a matter of policy reflection has been very limited.

We discussed above the codification of academic freedom and university autonomy in the EHEA. We would like to add an important observation here, which speaks to diverging paths as well, this time with respect to different political geographies.

The transformation of higher education on the continent through the Bologna Process and the involvement of the European Union was inspired and supported by new policy narratives, such as knowledge society and European integration (Matei 2015). These policy narratives have been accompanied by new epistemologies, which have influenced higher education, including in the area of academic freedom and university autonomy. Common European policy narratives and underlying epistemologies, together with a certain degree of coordinated action within the EHEA, have created the conditions for similar evolutions throughout the continent. This explains the common characteristics of university autonomy and academic freedom in the EHEA, as discussed here. 
Not all countries, though, have been equally committed to these narratives, which may explain national and regional differences in higher education policy. Moreover, in the last several years, the dominant narratives have lost their extraordinary force (Matei 2015) and new policy narratives, mainly of a populist and nationalist breed, have gained prominence. Democracy is in recession in many parts of the continent, and this affects higher education significantly. European integration is stalled and in some cases even reversed (Brexit is only one example). Some countries, mainly in the East, are now expressing less faith in the virtues of the knowledge society. Previously, the bet on the centrality of knowledge as a source of economic and social development was one of the most important elements of consensus in Europe. Now, this consensus is dissipating. The most relevant case, once again, although not the only one, is Hungary, whose prime minister stated repeatedly that what the country needs is not more knowledge or more students, ${ }^{11}$ but rather less higher education (which is somewhat of a "luxury", in his view and that of his Government) and more reliance on manual labour (Matei 2015).

Recently, changing policy narratives and epistemologies have resulted in changes of attitude towards universities; for example, they are considered less exceptional or exceptionally important. This is reflected in new regulations and practices, including for autonomy and academic freedom. As we have seen above, Hungary adopted a new constitution in 2010 and amended it a few times after that, all but erasing the provisions on academic freedom and university autonomy. In Russia, a different mix of policy narratives (emphasis on the knowledge society, yes, but less focus on Europe and consideration for democracy and human rights) created the condition for a different approach to academic freedom and autonomy throughout this period. In Turkey, an authoritarian regime with a nationalist-Islamic ideology went all the way to closing down entire universities and putting academics, administrators and students in prison (Caglar 2017), on the basis of allegations of connection to the Gülen movement, which appeared to be used as a catch-all shot to strike against uncomfortable political opposition, regardless of its real link to the failed coup attempt.

We could identify restrictions on academic freedom and autonomy in the West as well, but they are far from being comparable in magnitude and degree of salience. There are new lines of fracture in European higher education. One of them appears to be once again between the West and the East, and this is explained by the deeper fracture in terms of types of political regimes and ideologies.

Concepts such as policy narratives and higher education epistemologies, discussed below in more detail, can serve to explain the mechanisms by which the changing landscape of political regimes affects higher education and generates national/regional differences in higher education policies and practices.

\footnotetext{
${ }^{11}$ The number of students in Hungary decreased dramatically after 2010/2011 (Chikan 2017) going back to the low levels of 1998/1999 (https://dailynewshungary.com/number-university-studentshit-rock-bottom-hungary, accessed on 3 January 2018).
} 


\section{A European Notion of University Autonomy?}

We assert that a European model of university autonomy has emerged with and within the EHEA, and this is one of the most remarkable developments in university governance in the period after 1999-2000. In this section, we will summarise how this model emerged, its substance and characteristics and evidence indicating that it is consequential in Europe and beyond.

This model has been developed by the European University Association (EUA), established in 2001 through the merger of the Association of European Universities (CRE) and the Confederation of European Union Rectors' Conferences. There is no research available as yet to document and evaluate all the important contributions of EUA during this period. From direct experience (in part through direct participation in EUA projects) we feel confident to state that EUA has become rapidly one the most important, dedicated and influential actors in the EHEA.

Its formal mandate is to be the voice of European universities, support and take forward "the interests of individual institutions and the higher education sector as a whole". ${ }^{12}$ It has made numerous crucial contributions, usually in partnership with other organisations, covering almost all areas of higher education, from the definition of a European model of doctoral education (the so-called Salzburg Principles for Doctoral Education), to the development and adoption of the European standards and guidelines for quality assurance, the European qualifications framework for higher education or, more recently, reorientation of the policy focus within the Bologna Process on teaching and learning. EUA contributions have been made in various forms: effective advocacy at the European level, monitoring policy developments in specific areas (such as funding, governance, graduate education, research, etc.), undertaking applied research projects (usually ending in influential publications), initiation and participation in actual policy projects. The development of a European model of university autonomy is one of the most important and influential contributions of EUA, but it is not the only one.

EUA initiated an autonomy project in 2007, continuing until today. The project started as a survey "to provide a broad overview of national and institutional trends regarding autonomy and governance". ${ }^{13}$ EUA published a series of important reports (Estermann and Nokkala 2009; Estermann et al. 2011; Pruvot and Estermann 2017; EUA 2017) and created an interactive online autonomy tool as part of this project. ${ }^{14}$ The project involved applied research (or "studies", in the language of EUA), workshops and conferences, with contributions by EUA staff and external experts (including one of the co-authors of this chapter). Along the way, EUA developed a tool for measuring autonomy, called "Autonomy Scorecard", first published in 2011 (Estermann et al. 2011). In the most recent EUA

\footnotetext{
${ }^{12} \mathrm{http}: / /$ eua.be/About.aspx accessed on 15 December 2017.

${ }^{13}$ http://www.eua.be/activities-services/projects/past-projects/governance-autonomy-and-funding/ autonomy-scorecard-(2009-2012) accessed on 15 December 2017.

${ }^{14}$ http://www.university-autonomy.eu accessed on 3 January 2018.
} 
autonomy report, the immediate purpose of this entire endeavour is presented as being about "monitoring, comparing, and measuring different elements of autonomy" (Pruvot and Estermann 2017, p. 6). The ambition of the project, however, goes beyond just monitoring, comparing and measuring, as the same report acknowledges indirectly:

Discussions around university governance and autonomy emerged across Europe in different contexts as a response to different challenges. As a result, the need became manifest to develop a common terminology and structure to address such an important topic, with an increasing demand for comparability and benchmarking across borders (ibid, p. 7).

The project has already achieved more than just creating a tool for measuring, monitoring and benchmarking: it has articulated a European concept and model of university autonomy. This is one interesting example in public policy when an attempt at measuring resulted in important conceptual developments. It is also an illustration of how an attempt to "measure what we treasure", to use the title of a UN report assessing the progress in the implementation of the Millennium Development Goals (United Nations 2015), leads in the end to what we could call, with some concern, "treasure what we measure".

What are the main elements or substance of the model? It assumes that autonomy is a multidimensional concept, with four main independent dimensions: organisational, financial, staffing, and academic autonomy, each of them with a number of discrete sub-dimensions. For example, the sub-dimensions of financial autonomy are: length and type of public funding, capacity to keep surplus, capacity to borrow money, ability to own buildings, ability to charge tuition for national/EU students, ability to charge tuition for non-EU students. The project team (including external experts) has identified the four dimensions in consultation with the EUA individual and collective members (universities and national rectors' conferences) in the process of developing the Autonomy Scorecard in 2010-2011, based on the review of the literature and available data. A recent study by Orosz published in this volume appears to prove, using elaborated statistical analysis, that the four dimensions are indeed independent and, in this regard, the validity of the model is confirmed (Orosz 2018). The model further assumes that the four dimensions are necessary and sufficient to define autonomy. Other models of autonomy discuss either fewer or more dimensions (Matei and Iwinska 2014). Furthermore, this model assumes that autonomy can be measured exactly on each sub-dimensions and that actual values for each can change over time.

We can identify several elements of underlying epistemologies embedded in the EUA model. As discussed in this chapter, such elements can be inferred from the dominant policy narratives in the EHEA. The European integration policy narrative is reflected here in the conviction that a European-wide model or concept of autonomy is both possible and necessary. It is further implied that putting forward such a concept or model is a matter of active engagement (it needs to be created, or generated) rather than a matter of discovery (it is not the case that it exists "naturally" in Europe). The neo-liberal policy narrative is also immediately detectable. The final purpose of the exercise is to help create tools and policies, or elements of policy frameworks that would help increase the efficiency of universities: 
Institutional autonomy is widely considered as an important pre-requisite for modern universities to be able to develop institutional profiles and to deliver efficiently their missions (Pruvot and Estermann 2017, p. 7).

Although the model is about autonomy, which means at least in part about freedom, or freedoms, no moral arguments or reasons are mentioned, and the language of rights is not present. The focus is on efficiency. The concerns for efficiency, measurement and benchmarking explain why the model led to the development of a Scorecard which has been compared with a ranking. EUA itself made it clear the Scorecard was not meant to be a ranking (ibid). The success of the Scorecard, however, as expressed in the large degree of public attention it has received, has to do in part with its capacity to present a kind of league tables (for systems, not for individual institutions, though) which, in turn, made it easy to use by the media, policymakers or universities themselves, in a manner similarly to the rankings, in which entire countries or systems are ranked depending on the degrees of autonomy in their universities on these four dimensions.

A third element of situated epistemology here refers to the knowledge society. The EUA model is based on the conviction or belief that knowledge is fundamental to the political, social and economic advancement of Europe and, therefore, it is important to put in place the requisite conditions for universities to make their necessary contribution to the creation and use of knowledge. Autonomy is understood to be both a necessary condition for achieving efficiency (the words "rights" or "necessary freedoms" are not used) and a responsibility, both for the university themselves (practice it responsibly, with accountability, and efficiently) and for the policymakers (make sure regulatory systems supportive of autonomy are in place).

Although still very young, the model has become consequential in Europe and beyond. It has become a reference in policy discussions and major policy initiatives and reforms, in moments of expansions but also contraction of the space for autonomy. The publication of the EUA autonomy reports and of the two editions of the scorecard, in particular, attracted each time a lot of attention in the media in Europe. The EUA online autonomy tool is regularly used by scholars, university administrators and policymakers. It is the only such tool allowing for benchmarking of autonomy available in Europe and probably in the world. In Hungary, media outlets and universities have used the Autonomy Scorecard to denounce the restrictions imposed by the government through a series of restrictive legislatives legislative reforms mentioned. A comparison of the 2011-2016 Autonomy Scorecard results indicates that Hungary has moved downwards in the rankings in most of the autonomy dimensions, from being placed 6th to 28th on the financial autonomy dimension, from 16th place to 23rd in organisational autonomy, and from 17th to 22nd in staffing autonomy. Only the position of academic autonomy appears improved and moved up from 24 to 16 (Kenesei 2017). A major set of reforms undertaken by the Government of Kazakhstan, this time to enhance the autonomy of public universities rather than restrict it, has been based on the EUA model and has been implemented with help from EUA or associated experts. 
Reporting on these reforms, Alpysbayeva and Akhmetzhanova published an article with the exact title "Reforming university autonomy in Kazakhstan: a project to evaluate the current status and generate precise reform directions using the EUA university autonomy tool" (Alpysbayeva and Akhmetzhanova 2016). At present, the Government of Kazakhstan implements a EU funded project called "Transition to University Autonomy in Kazakhstan", which is led by EUA itself. ${ }^{15}$ In Myanmar, a country far away from Europe, the reform of university autonomy is a major part of the transformation of higher education currently taking place after several decades of dictatorship and repression of higher education. This reform of the regulatory framework for autonomy is led by the ministry of education and a national education policy commission appointed by Parliament, with the support of international partners (mainly Central European University), and it is based on the EUA model as well.

The concept of university autonomy remains a contested one and it has multiple and evolving understandings in the EHEA and in the world. The EUA model has become a common European reference, conceptually and operationally, and it is increasingly influential in other parts of the world as well.

\section{Conclusion}

The chapter identifies diverging paths of development within and between academic freedom and university autonomy. These distinct but related areas of university governance have developed differently as part of the broader EHEA evolutions. Academic freedom has become a disregarded and underdeveloped area. University autonomy, in turn, has benefited from a lot more attention. A European model of university autonomy has emerged within the EHEA, initially driven by a desire to monitor and measure autonomy. This model is now influential beyond just Europe. As is often the case in public policy, an exercise in measuring has become an exercise in definition and codification. The emergence of this model has been influenced by a mix of powerful policy narratives in higher education (e.g. knowledge society, European integration, neo-liberal democratic development). Conceptually, the evolution of both university autonomy and academic freedom in Europe has been influenced by specific epistemologies embedded in these policy narratives.

A tendency to focus on instrumental aspects of governance can be identified during the period studied (from 1999 to 2000 until today), linked to the preoccupation for increased efficiency of universities as "delivery organisations" at the service of the knowledge societies. This tendency explains to a large extent the specific nature of the EUA model of autonomy. It also explains why academic

\footnotetext{
${ }^{15} \mathrm{http} / / / \mathrm{www} . e u a . b e /$ activities-services/projects/current-projects/governance-funding-publicpolicy/transition-to-university-autonomy-in-kazakhstan accessed on 3 January 2018.
} 
freedom tended to be ignored. More generally, it helps to explain the decreasing attention to moral aspects and rights (including from a legal perspective) in the discussion about autonomy and academic freedom, how they can be codified, promoted and protected.

Based on this analysis, it appears necessary to pay attention to both academic freedom and autonomy in the EHEA. Academic freedom, as a special, regulated freedom (or freedoms) of individuals in the university, must not be sacrificed on the altar of autonomy, understood as freedom of the institution.

An influential 20th century report on higher education found that in order to "perform its mission in the society, a university must sustain an extraordinary freedom of enquiry and maintain an independence from political fashions, passions, and pressures" (Kalven report 1967, p. 1). For the specific case of the EHEA, Bergan et al. rightly point out that, even more than that, academic freedom and institutional autonomy "are essential to democratic societies, and they are essential to improving and maintaining the quality of higher education and research" (Bergan et al. 2016, p. 2).

We need to recognise in Europe that both university autonomy and academic freedom are needed. In addition, we need to reinsert the rights perspective, together with the instrumental one, on both.

While universal definitions might not be useful or even possible, a European-wide endeavour of reflection on, and monitoring of both academic freedom and university autonomy is needed. Moreover, if the EHEA as a continent-wide, supranational space for policy dialogue and practice in higher education is to stay and develop, efforts for a European codification of both should be imagined, preferably with a legal value as well. These tasks could be assumed by new or existing organisations and bodies, such as the Magna Charta Observatory (provided it can find the resources), EUA, or some EHEA structures (perhaps the Bologna Follow-Up Group). We realise that any particular choice regarding who would assume this endeavour implies different routes and degrees of feasibility, given the different status of the respective organisations (e.g. voluntary expert body, association, intergovernmental). In the end, we need to remember that what is at stake is important and it is not primarily a theoretical or conceptual matter, but a practical and moral one. Universities in Europe could not fulfil their mission in the absence of good regulatory frameworks and practices for governance.

\section{References}

Abrami, R. M., Kirby, W. C., \& McFarlan, F. W. (2014). Why China can’t innovate. Harvard Business Review.

Alpysbayeva, M., \& Akhmetzhanova, A. (2016). Reforming University Autonomy in Kazakhstan: A project to evaluate the current status and generate precise reform directions using the EUA University Autonomy tool. Journal of the European Higher Education Area, 6(1), $27-47$. 
Beiter, K. D., Karran, T., \& Appiagyei-Atua, K. (2016). "Measuring” the erosion of Academic Freedom as an International Human Right: A report on the legal protection of Academic Freedom in Europe.

Bergan, S., Egron-Polak, E., Noorda, S., \& Pol, P. (2016). Academic freedom and institutional autonomy. What role for the EHEA? Paper presented at the Background document for the thematic session at the meeting of the Bologna Follow-Up Group, Bratislava. Retrieved from https://media.ehea.info/file/20161208-09-Bratislava/12/8/BFUG_SK_ME_52_9_

Fundamental_values_669128.pdf.

Bucharest Communiqué. (2012). Making the most of our potential: Consolidating the European Higher Education Area. Bucharest Communiqué. Paper presented at the EHEA Ministerial Conference. Retrieved from https://media.ehea.info/file/2012_Bucharest/67/3/Bucharest_ Communique_2012_610673.pdf.

Caglar, A. (2017). Blow by blow: The assault on Academic freedom in Turkey. Eurozine. Retrieved from http://www.eurozine.com/blow-by-blow-the-assault-on-academic-freedom-inturkey.

Chikan, A. (2017). Key developments in Hungarian higher education. In M. Ignatieff \& S. Roch (Eds.), Academic freedom. The global challenge. Budapest: CEU Press.

Council of Europe. (2006). Recommendation 1762. Academic freedom and university autonomy. Parliamentary Assembly of the Council of Europe. Retrieved from http://assembly.coe.int/nw/ $\mathrm{xml} / \mathrm{XRef} / \mathrm{Xref}-\mathrm{XML} 2 \mathrm{HTML}-\mathrm{en}$.asp?fileid=17469\&lang=en.

Council of Europe. (2012). Recommendation CM/Rec(2012)7 of the Committee of Ministers to member States on the responsibility of public authorities for academic freedom and institutional autonomy. Retrieved from http://www.refworld.org/pdfid/50697ed62.pdf.

de Boer, H., \& Jongbloed, B. (2012). A cross-national comparison of higher education markets in Western Europe. In A. Curaj, P. Scott, L. Vlasceanu \& L. Wilson (Eds.), European higher education at the crossroads: Between the Bologna Process and national reforms. Berlin: Springer.

Enders, J., de Boer, H., \& Weyer, E. (Eds.). (2012). Regulatory autonomy and performance: The reform of higher education re-visited (Vol. High Educ). Media. Dordrech: Springer Science + Business.

Estermann, T., \& Nokkala, T. (2009). University Autonomy in Europe I-Exploratory study. Brussels: European University Association.

Estermann, T., Nokkala, T., \& Steinel, M. (2011). University Autonomy in Europe II. The Scorecard. Brussels: European University Association.

European Commission. (2006). Delivering on the Modernisation Agenda for Universities: Education, Research and Innovation. Communication from the European Commission to the Council and the European Parliament. Brussels, 10.5.2006 COM (2006) 208 final.

European Commission. (2017). Press release. Commission refers Hungary to the European Court of Justice of the EU over the Higher Education Law Brussels [Press release]. Retrieved from http://europa.eu/rapid/press-release_IP-17-5004_en.htm.

European University Association. (2017). University Autonomy in Europe III. Country Profiles. Bruxelles: European University Association.

Forsyth, H. (2014). Disinterested scholars or interested parties? The public's investment in self-interested universities. In M. Thornton (Ed.), Through a glass darkly: The social sciences look at the Neoliberal University. Australian National University Press.

Gornitzka, A., Maassen, P., \& de Boer, H. (2017). Change in university governance structures in continental Europe. Higher Education Quarterly, 71, 274-289.

Hungarian Government. (2017). Magyarország elküldte válaszleveleit az Európai Bizottságnak a felsőoktatási törvény és civil törvény miatt inditott kötelezettségszegési eljárásokkal kapcsolatban. Retrieved from http://www.kormany.hu/hu/igazsagugyi-miniszterium/parlamentiallamtitkarsag/beszedek-publikaciok-interjuk/magyarorszag-elkuldte-valaszleveleit-az-europaibizottsagnak-a-felsooktatasi-torveny-es-civil-torveny-miatt-inditott-kotelezettsegszegesieljarasokkal-kapcsolatban. 
Kalven report. (1967). Report on the University's Role in Political and Social Action. Report of a faculty committee under the chairmanship of Henry Kalven Jr. Committee appointed by President George W. Beadle. Record, 1(1).

Karran, T. (2009). Academic Freedom in Europe: Time for a Magna Charta? Higher Education Policy, 22, 163-189.

Kenesei, I. (2017). University Autonomy in Hungary in perspective. In M. Ignatieff \& S. Roch (Eds.), Academic Freedom. The global challenge. Budapest: CEU Press.

Marginson, S. (2016). The Public Dimension of Universities. In P. Scott, J. Gallacher, \& G. Parry (Eds.), New languages and landscapes of higher education. Oxford Scholarship.

Matei, L. (2012). A policy gap: Financing in the European Higher Education Area. In A. Curaj, P. Scott, L. Vlasceanu, \& L. Wilson (Eds.), European Higher Education at the crossroads: Between the Bologna Process and national reforms (pp. 553-572). Dordrecht, Heidelberg, New York: Springer.

Matei, L. (2015). The future of higher education and "the European level". In A. Curaj, L. Matei, R. Pricopie, J. Salmi, \& P. Scott (Eds.), The European Higher Education Area: Between critical reflections and future policies. Heidelberg, New York, London: Springer International Publishing.

Matei, L. (2017). Three ideas of academic freedom. In M. Ignatieff \& S. Roch (Eds.), Academic Freedom. The global challenge. Budapest: CEU Press.

Matei, L., \& Curaj, A. (2014). Building an integrated higher education system in Europe: Romania's commitments in the European Higher Education Area and their implementation at national level. Budapest: CEU Press.

Matei, L., \& Iwinska, J. (2014). University Autonomy: A practical handbook. Budapest: Yehuda Elkana Center for Higher Education.

Matei, L., \& Orosz, K. (2017). Central European University: An exceptional moment for Hungary, and for International Higher Education. World Education News and Reviews, June 2017.

Matei, L., Craciun, D., \& Torotcoi, S. (2018). A resounding success or downright failure? Understanding policy transfer within the Bologna Process in Central and Eastern Europe. In A. Batory, A. Cartwright, \& D. Stone (Eds.), Policy experiments, failures and innovations beyond accession in Central and Eastern Europe. Cheltenham: Edward Eldgar Publishing.

Orosz, K. (2018). Interconnected dimensions of University Autonomy in Europe. In this volume.

Pruvot, E., \& Estermann, T. (2017). University Autonomy in Europe III. The Scorecard 2017. Bruxelles: European University Association.

Ren, K., \& Li, J. (2013). Academic Freedom and University Autonomy: A Higher Education Policy perspective. Higher Education Policy, 26, 507-522.

Sagintayev, A., \& Kurakbayev, A. (2015). Understanding the transition of public universities to institutional autonomy in Kazakhstan. European Journal of Higher Education, 5(2).

Scott, P. (2012). The Bologna Process has been key to European universities'success. Retrieved from http://www.theguardian.com/education/2012/apr/30/bolognaprocess-key-europeanuniversity-success.

Tarrach, R. (2017). Foreword. In E. Pruvot \& T. Estermann (Eds.), University Autonomy in Europe III. The Scorecard 2017. Bruxelles: European University Association.

Tausz, K. (Historical foundations of academic freedom in Hungary). (2017). In M. Ignatieff \& S. Roch (Eds.), Academic Freedom. The global challenge. Budapest: CEU Press.

UNESCO. (1997). Recommendation concerning the Status of Higher-Education Teaching Personnel.

United Nations. (2015). The Millennium Goals Report 2015. Retrieved January 5, 2018, http:// www.un.org/millenniumgoals/2015_MDG_Report/pdf/MDG\%202015\%20rev\%20(July\% 201).pdf.

Vögtle, E. M., \& Martens, K. (2014). The Bologna Process as a template for transnational policy coordination. Policy Studies, 35(3), 246-263. 
Vukasovic, M., Jungblut, J., Chou, M.-H., \& Ravinet, P. (2018). Multi-level, multi-actor and multi-issue dimensions of governance of the European Higher Education Area and beyond. In this volume.

Zhao, Q., \& Hayhoe, R. (2014). The "Beijing Consensus" and the Chinese model of University Autonomy. Frontiers of Education in China, 9(1), 42-62.

Open Access This chapter is licensed under the terms of the Creative Commons Attribution 4.0 International License (http://creativecommons.org/licenses/by/4.0/), which permits use, sharing, adaptation, distribution and reproduction in any medium or format, as long as you give appropriate credit to the original author(s) and the source, provide a link to the Creative Commons license and indicate if changes were made.

The images or other third party material in this chapter are included in the chapter's Creative Commons license, unless indicated otherwise in a credit line to the material. If material is not included in the chapter's Creative Commons license and your intended use is not permitted by statutory regulation or exceeds the permitted use, you will need to obtain permission directly from the copyright holder.

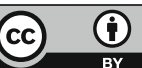

